\title{
The foundation, value and meaning of baptism in the New Testament ${ }^{1}$
}

\author{
Jonanda Groenewald ${ }^{2}$ \\ Department of New Testament Studies \\ University of Pretoria
}

\begin{abstract}
In the symbolical and social world of the first Christians, baptism functioned as a "cultural symbol". Ensuing from Gerd Theissen's (1999) work, A theory of primitive Christian religion, the paper explains the opinion that religion, defined as a system of cultural symbols, consists of sacred mythical narratives conveying ritual values which can be internalized through participation. Theoretically argued, there is a historical reason why a specific symbol/rite fits the social context. Behind the contextualized rite lies an idea which communicates values and provides meaning. From the textual evidence in the New Testament, this article demonstrates the historical foundation, the value and meaning of being baptized.
\end{abstract}

\section{INTRODUCTION}

This paper is about the question as to the reason why the earliest followers of Jesus let themselves be baptized. In his book, $A$ theory of primitive Christian religion, Gerd Theissen (1999) explains that baptism functioned as a cultural ritual symbol for the first followers of Jesus. In this paper Theissen's insights will be outlined and elaborated on by looking at the question what a symbol is and how baptism symbolized an alter state of consciousness in the early church. A

\footnotetext{
${ }^{1}$ Paper presented at the Annual Congress of the New Testament Society of South Africa, University of Natal, 22-25 April 2003. Jonanda Groenewald is a DD candidate in the Department of New Testament Studies, University of Pretoria.

2 Financial assistance from the Mellon Foundation is hereby acknowledged. Opinions expressed in this research, or conclusions drawn, are those of the author and not necessarily of the Mellon Foundation.
} 
symbol conveys meaning in that a signifier points to the signified (see Cassirer 1944:31-32; Turner 1967:19). An alter state of consciousness is a spiritual existence in which someone experiences the sacral in a symbolical way to gain meaning in everyday social life.

Theoretically argued, there is a historical reason why a specific symbol fits the social context. According to the social anthropologist John Beattie (1964:6971) an idea which communicates values and provides meaning lies behind a contextualized rite. For some the values which give meaning to life can be found in religion. Religion is embedded in a cultural system. This system is dialectically influenced by a symbolic universe, which functions as a kind of "sacred canopy" (see Berger 1969). Baptism as religious practice reflects this dialectical relationship. From the textual evidence in the New Testament, this paper aims at demonstrating the historical foundation, the value and meaning of being baptized.

\section{RELIGION AS A CULTURAL SIGN SYSTEM}

Theissen (1992:2) defines religion as “... a cultural sign language which promises a gain in life by corresponding to an ultimate reality" (cf also Geertz 1973:90). According to Theissen (1999:2), this cultural sign language has a semiotic, systematic and cultural character.

\subsection{The semiotic character of religion}

People do not only exist in their environment; they make it habitable by fulfilling social roles, using technology and interpreting their interaction with people and objects. This interpretation pertains to the activities of science, art and religion. The transformation of the world through interpretation is a symbolic action, a interaction which consists of a referential relationship between a signifier and signified. Life has a semiotic character. It is not signs and sign systems which alter the signified reality, but our cognitive, emotional and pragmatic relationship to signs and sign systems. The semiotic nature of life determines our 
consciousness, transforms our perceptions into patterns. Our consciousness and perceptions influence our actions (cf Cassirer 1944:25-26; Theissen 1999:2).

The distinctive feature of a religious sign system is the combination of myth, rites and ethics (Theissen 1999:2; cf Stolz 1988b:79-147). Myths function on an unconscious level and manifest in narrative form. Social behavior and interaction can be explained by identifying their mythical roots (cf Cassirer 1955; Malinowski 1971:11-35; Bolle 1987:261; Stolz 1988a:81-106; Theissen 1999:3, 325). A rite is a cultural form of this social activity. Rites are recurrent patterns of behavior which interrupt everyday life. In this way the sacred becomes present in the mundane. This sacral reality represents "another reality", an alter state of consciousness, the mythical narrative of someone's life. Rites consist of ritual formulae (which interpret the mythical narrative) (cf Lang 1998:442; Theissen 1999:3). All forms of religious sign language, for example a rite, represent a specific ethical consciousness (cf Theissen 1999:4).

\subsection{The systematic character of religion}

"Signs" function in relation and opposition to other signs to form a "system". These signs and forms of a religion constitute its "language" which is guided by rules, just as a language is governed by grammar and vocabulary (Theissen 1999:4; cf Lindbeck 1984:33, 81, 95-96; Ritschl 1986:147-166).

\subsection{The cultural character of religion}

The word "cultural" indicates that religious sign language is produced by human beings, irrespective of the dimension of religion. To confer meaning on "material elements" (such as water, bread and wine) and to organize these meanings into a ritual system (such as Baptism and Holy Communion) is a social action. Such a sign system becomes effective through the participation of individuals in a group. Religion as a social cultural sign system is embedded in a historical context. Religions originate, disappear and mix because of how groups engage in history (cf Theissen 1999:6-7). 
The religion of the early church as a sign system thus consisted of three elements: a narrative sign language which indicated how myth functioned in social life, a prescriptive sign language communicating values (meaning found by means of participation in ritual events) and a ritual sign language in the form of Baptism and Holy Communion.

\section{THE ORIGIN OF THE EARLY CHRISTIAN BAPTISM}

\subsection{Origin}

The origin of the early Christian baptism is uncertain. ${ }^{3}$ Collins (1996:218) suggests that early Christian baptism originated from the baptismal practice of John ${ }^{4}$ (cf Oepke 1968:536-538; Reicke 1987:219; Theissen \& Merz 1996:193194). Therefore, it is necessary to understand the nature of the baptism performed by John (see Boers 1989:31). John's baptism was most probably influenced by the Levitical washings (full immersion in water) and the propheticapocalyptic tradition (according to which a definite intervention of God was expected in the future) (see Collins 1996:218-229; Theissen \& Merz 1996:187194). John created a new rite by changing the ritual washings of the Second Temple period to a single baptism functioning as an initiation into God's eschatological kingdom. By performing this rite (baptism for the forgiveness of sins) only a few miles from the Jerusalem temple, John challenged the traditional rites of atonement. John's baptism proclaimed a new life for those who repented and were willing to live according to a radically new ethic (Theissen 1999:126128). The significance of John's baptism is best understood in terms of a

\footnotetext{
${ }^{3}$ The origin of the early Christian baptism has been sought in the mystery religions, in the Old Testament regulations concerning ceremonial cleansing, in proselyte baptism and in the baptism practices of sects like Qumran. Although there are similarities, none of these practices answer the question concerning the origin of the early Christian baptism satisfactorily (see Pelser 1981:247-251; cf Jeremias 1960:24-37; Oepke 1968:532-536; Meyer 1987:17-30, 155-196; Pearson 1999:42-62).

4 The baptism of John was most probably the best known in the early church; it features prominently in early Christian literature (see Ac 10:37-38; 13:24-25; Gospel of the Nazarenes, in Hiëronimus, Contra Pelagius 3.2; Gospel of the Ebionites, in Epiphanius, Heresies 30.13.7 - see Tatum 1994:89-90).
} 
prophetic reinterpretation of the purity ideology: obedience to the new ethic safeguards against apocalyptic judgment (see Crossan 1996:46-49; Theissen 1999:126; cf Pelser 1981:252-253; Collins 1996:229; Hooker 1997:9-13).

Jesus probably did not baptize ${ }^{5}$ but was baptized by John. According to Van Aarde (2001a:55-57) Jesus, after his baptism, returned to Galilee where he lived according to the ethic as intended by John's baptism. Although John and Jesus had different eschatological views, ${ }^{6}$ they agreed on the fundamental distinction between God's kingdom and the kingdoms of the world (Van Aarde 2001a:72). A continuity of the understanding that John, Jesus, and the early Jesus followers had regarding the meaning of baptism can be constructed (cf Bultmann 1972:253; Pelser 1981:252-252). The early followers of Jesus reinterpreted the baptism with water as a spiritual baptism, which represents "another reality" (an alter state of consciousness). In the past scholars referred to this as an "eschatological" event. However, early Jesus followers understood baptism with water spiritually (representing a "mythical" experience of an alter state of consciousness in "historical time" - see Otzen [1976] 1980:7; cf Eliade 1955:68-70, 104-105) as a symbolical reference to their participation in the death of Jesus (a baptism into the death of Jesus - see Paul in Rm 6:4) (cf Theissen 199:125-126).

A transformation of "iconic relationships" took place. The symbolic action of baptism with water was reinterpreted as a symbolic baptism into the death of Jesus. The symbol of water refers to purity and reminds participants of the traditional purity ideology which was challenged by John. The symbol of death indicates impurity and reminds participants of how Jesus brought an end to the previous ideology by means of his death. This is "a dissolution of the iconic

\footnotetext{
${ }^{5}$ According to the Synoptic Gospels Jesus' public ministry only started after John's came to an end (Mk 1:14; Mt 4:12-17; Lk 3:18-23) whereas, according to the Gospel of John, Jesus and John worked at the same time (Jn 3:22-30; 4:1-3). Adela Collins (1996:230-232) is of the opinion that the Gospel of John is a reflection of what happened historically. However, most scholars (e.g., Pelser 1981:251-252; Schweitzer 1930:160-162; Jeremias 1978:48-49; Boers 1989:39-40; Theissen 1999:126-127) regard John's preaching and baptism only as preparation for Jesus' ministry.

6 John expected an imminent end. Jesus proclaimed the kingdom of God as a present fulfilled reality (Jeremias 1978:48-49).
} 
relationships" (Theissen 1999:128). The previous ritual taboo (contact with the dead) has been terminated. This radical change requires an adaptation of ritual practice and it implies a radically new ethic.

\subsection{Reference to the death of Jesus}

According to Luke, John expected one "stronger" than he to introduce a final baptism - one with fire and spirit (Lk 3:16-17; Ac 8:14-17). This indicates that followers of Jesus identified him as this "stronger one" (Jn 1:33; 3:22, 26; 4:1-2; see Collins 1996:233-234). "Baptism with the Spirit" is synonymous with being baptized in the "name of Jesus" (Mt 28:19; Ac 2:38; cf Oepke 1968:539-540; Collins 1996:235). This baptism was John's baptism for the "forgiveness of sins" (Mk 1:4). The general conviction of early Jesus followers was that the forgiveness of sins was made possible through the death of Jesus (see 1 Cor 15:3-5; 2 Cor 5:21; Rm 4:24-25; 6:3-11, 22-23). "Thus there was an intrinsic necessity for baptism for the forgiveness of sins in the name of Jesus also to be related to the death of Jesus. The salvation gained through the death of Jesus was promised to the baptized through baptism as the forgiveness of sins through a verbal promise and the non-verbal language of the rite" (Theissen 1999:129; cf Van Aarde \& Pelser 2001:37-40).

There are two possible historical reasons for this later interpretation of baptism as a symbolic dying and being buried with Christ. The first is the symbolic dramatization of the experience of death in Hellenistic-Semitic and Greco-Roman initiation rites (e.g., the Isis cult) (cf Van Staden 2001:582). In analogy to this, the early Jesus followers interpreted baptism as a symbolic experience of death. Secondly, in early Christianity the metaphorical act of baptism could result in actual death because of Roman imperial antagonism against this "superstition" (see, e g, the reference from hindsight to the death of the sons of Zebedee in Mk 10:38; cf Collins 1996:237; Theissen 1999:129).

In early Christian literature the link between baptism and death is first found in the writings of Paul (e g, Rm 6:4; see Hooker 1997:9; Campbell 1999:273-293). Paul's message to the Gentiles called for a radical conversion, 
both mentally and socially. Symbolically, it required of the person to die with Christ, in order to begin a completely new life with Christ (Theissen 1999:129130). For the Mediterranean personality this new life symbolizes an alter state of consciousness (see Pilch 1993, 1996, 2002a, 2002b).

\subsection{Tension between outward performance and religious significance}

Because of its reference to the death of Jesus, the new rite of baptism lost its visible or "iconic" character. Where a cleansing with water can easily be understood as an image of inner cleansing, this early Christian sacrament had an aniconic character. Baptism is not an image of the death of Jesus - there is no visible relationship between baptism and death/burial (Theissen 1999:132; see Pelser 1981:254-255). The ethical value early Jesus followers attached to baptism was not illustrated by an iconic association between the ritual event of baptism and its religious meaning. A narrative now communicated this value and meaning. This narrative conveyed the reason why the early followers of Jesus performed the ritual of baptism.

\subsection{Crossing of taboo thresholds}

Strictly speaking, Paul does not identify baptism with death, but with being buried (Rm 6:4; see Wedderburn 1987:368-371). Just as burial is a confirmation that death has taken place, so baptism as being buried with Christ is the external confirmation of the spiritual dying with Christ (Theissen 1999:134). The metaphor of grave and burial enters the realm of taboos. For Israelites graves were unclean. In the early Christian interpretation of baptism it is the grave where the old person is left behind in order that the person may attain new life and salvation. People who were baptized died symbolically and attained salvation (Theissen 1999:134; see Mc Fague 1983:15; Soskice 1985:15). Being baptized expresses symbolically the overcoming of anxieties related to social contact. In GI 3:28 Paul hands down a baptismal tradition according to which those who were baptized "clothed" themselves with Christ: "There is neither Jew nor Greek, slave nor free, male nor female, for you are all one in Christ Jesus". If 
one envisages how many taboos can be imposed to maintain the social differences mentioned here, one can judge the magnitude of the step taken by the baptized towards overcoming such social taboos (Theissen 1999:134).

Baptism as cultural ritual symbol explains the reason why Christians let themselves be baptized, the value they attached to their baptism and the meaning that it had for their lives. It reminds them of John's temple critique and Jesus' death as the termination of the temple ideology. It expresses the dissolution of selfish exclusive social taboos. It provides the motivation to live ethically according to Jesus' vision and to find existential meaning despite threats of being killed themselves.

\section{BAPTISM AS A CULTURAL RITUAL SYMBOL}

\subsection{A ritual symbol}

The reason for baptism as a symbol for overcoming a social taboo has historical roots. The "cult" of the early Jesus followers consisted of a symbol structured on the basis of the cult of the Second Temple period (cf Theissen 1999:286). In order to become part of Israel an individual had to undergo an initiation rite circumcision. By means of circumcision a male baby was made part of the covenant between God and Abraham (Gn 17:7-14). This rite took place on the eighth day after birth. For Israel it was a physical sign of being part of the people of God (see Knobel 1987:392-393; Hyatt 1989:629-631).

The early Christian religion soon became an autonomous symbol system, which started with Jesus' preaching of the kingdom of God after his baptism by John (cf Theissen 1999:286-292). Circumcision was exclusively for men, whereas Jesus' message contained new values. For instance, no distinction was made between men and women. Jesus understood God's presence differently. This meant that a new initiation rite had to be found. Baptism as initiation rite made it possible for all people to become part of the kingdom of God.

Circumcision initiates people into Israel in a physical way. In the Gospels the kingdom of God stands in relation to the redefined Israel who live in the 
presence of God. Paul sees this "Israel of God" (GI 6:16) as a new creation (2 Cor 5:17). In the Gospels and in Paul's letters the expression "kingdom" has a political connotation (cf Elliot 2000:25). The kingdom of God is an alternative to the kingdom of Caesar in Rome (see Crossan 1998:413). A life in the presence of God means to simply enter it as a child (Mk 10:14-15). In order for an adult to live as a child, an alternative state of being is required. A rite can bring about this cultural-psychological alter state of consciousness. Through baptism people who become part of the kingdom of God, undergo a symbolic status transformation from the biological-physical world to the world of God.

\subsection{An initiation and status transformation rite}

Baptism is a rite de passage. ${ }^{7}$ In a symbolic way rites like these represent the legitimate crossing of a boundary, which bring along a new identity with new rights and responsibilities. These rites assign people a location in cultural space and designate them a status that the other members of society recognize as proper (Van Staden 2001:583; cf McVann 1991b:333).

There are certain elements that allow this transition (to a new status) to take place effectively, namely the initiands, who undergo the change of role or status; the ritual elders, who preside over the ritual; and the symbols of the new world, which the initiands learn during the ritual (Van Gennep 1960:21, 65-115; McVann 1988:97; 1991a:152-153; 1991b:336; see Turner 1967:94-108, 235-236; cf Wedderburn 1987:363).

The ritual process of status transformation takes place in three phases: separation from society, demarcation against society and reintegration into society (McVann 1991b:338; see Van Staden 2001:585).

\footnotetext{
7 Arnold van Gennep first used the term rites de passage in 1909. According to him it describes two types of rites: rites that accompany the passage of a person from one social status to another in the course of life (e.g., birth and marriage) and rites that mark recognized points in the passage of time (e.g., new year and new moon) (Turner 1987:386; see Myerhoff, Camino \& Turner 1987:380-383; Wedderburn 1987:363; McVann 1991b:335-336; Gehlen 1998:58-63; cf Girard 1972:425).
} 


\section{- Separation}

People undergoing status transformation rituals experience separation in three ways: separation from people, place and time. Participants are separated from the ordinary rhythm of the group. At the point of ritual separation, the initiands and the place of initiation become "off limits" to everybody who does not have a role to play there. It is important to remove the initiands to a place separated from the locus of ordinary life because the experience into which they will enter is "out of the ordinary". The participants in a ritual are removed from the normal flow of time. They leave "secular" time and enter into a sacred "timelessness". The usual times for eating, sleeping, working and learning are altered (McVann 1991b:338-339; cf Turner 1967:97, 223-226).

\section{- $\quad$ Liminality-Communitas}

Turner (1967:99-102) describes the process of demarcation against the society as liminality-communitas. Liminality, the negative side of the ritual process, describes the state into which the initiands are brought by virtue of their separation from their everyday, familiar world. During this period initiands become disoriented, having been cut off from the persons, points of reference and activities which shaped their previous way of living. In a sense they "disappear" from view, or "die". They are required to abandon their previous habits, ideas and understandings of their personal identity, as well as their social relations. Their previous identities are no longer operative, but they have not yet acquired new roles and statuses. Therefore they are "in between" and perceived to be dangerous (McVann 1991b:339; see Turner 1969:95; Wedderburn 1987:367-368).

Communitas, the positive side of the ritual process, refers to the initiands' recognition of their fundamental relation to the institution into which they are being initiated. All the distinctions between the initiands disappear and equality and unity are emphasized (McVann 1991a:153; 1991b:340; see Turner 1967:99$101 ; 1974: 46)$. $^{8}$

${ }^{8}$ Certain status transformation rites require some form of ritual confrontation which needs to end successfully in order to gain public recognition. The initiands are tested to see whether the skills of the new role have been learned and to apprise whether the initiands are committed to the charge laid upon them (McVann 1991b:350; cf Turner 1969:100-102; Girard 1972:147-149, 179180, 409-462). 


\section{- Aggregation}

With the ritual process completed, the initiands return to society with new roles and statuses as well as with new rights and obligations. Society acknowledges that the initiands now have the capabilities required for their new roles. Their status in the community has been redefined (McVann 1991a:153; 1991b:340; cf Turner 1967:251-260).

Since Jesus followers saw baptism as a rite of status transformation (McVann 1991a:151; see Wedderburn 1987:363-371), ${ }^{9}$ they "marginalized" themselves by rejecting their previous relations. After this separation, they found themselves in a state of liminality. They had to "die" with Christ, in order to be able to live a new life. Since all new Jesus followers went through the same process, they also found themselves in a state of communitas. Every person who received baptism was now free from everything the old regime represented. They were part of a new regime with new values (Myers 1990:129; see Wedderburn 1987:369). They were integrated into a new community.

Baptism as a ritual reenactment of Jesus' death and resurrection, conveyed the message that it was possible to conquer death by having faith in Jesus. The new status, for which baptism had prepared a person, was discipleship in the way of the cross. Baptized people followed Jesus across the boundary of death to life (McVann 1991a:152, 156).

All the different stages of a status transformation rite are thus clearly present in early Christian baptism. ${ }^{10}$

9 Using Mk 1:9-13, Van Eck (1995:288-291) shows that Jesus' baptism was also a ritual of status transformation. McVann (1991b:341-358) does the same with Lk 3:1-4:35 (cf Jeremias 1978:5156; Waetjen 1989:68-69). Jesus needed to undergo a status transformation in order to become the new mediator of God's kingdom and God's presence.

10 Some examples from the New Testament: In 1 Cor 12:12-13 Paul explains baptism as the way in which Jew, Greek, slave and free becomes part of a "pneumatic body" - an alternative state of being. Baptism shows that, although the body has different parts, it functions as a unit. Baptism is a symbol that shows that the Spirit of God overcomes all the differences in this pneumatic existence (see also GI 3:26-29). Paul also refers to baptism as dying and being buried with Christ. This shows the safe shift of the person being "buried" from one kind of being to another from "in sin" (Rm 6:2) to "in Christ" (Rm 6:11), from "death" to "life" (Rm 6:13). The finality of the change is shown by associating baptism with a burial (Wedderburn 1987:368-369; Meeks 1993:94-95). By the time that the deutero-Pauline Letter to Colossians was written (see Van Aarde \& Pelser 1994:32-36), baptism was generally seen as an initiation rite. By this time it was regarded as a "new circumcision" (Col 2:11; see Collins 1996:235). In the shift from a Pauline to a deutero-Pauline context, we see a shift form a state of liminality to a state of communitas. 


\section{THE FOUNDATION, VALUE AND MEANING OF BAPTISM IN THE NEW TESTAMENT}

Symbols function as expressions of a new value system. The ethics of Jesus brought about a "new world" (Duling \& Perrin 1994:356). Although this ethics manifested throughout Jesus' life, his death and resurrection were the epitome of it. The historical foundation of baptism among the Jesus followers was that Jesus abandoned the old value system (through his death) and led his followers (through his resurrection) to a new life in the service of God.

What was especially new in this value system was the love of the neighbor and humility (or renunciation of status) (Theissen 1999:63, 343-360; cf Schrage 1988:70-73, 76-78, 99, 106-107). These two values correlate with the fundamental dimensions of social relationships. Love of the neighbor has to do with the relationship between the inside group and the outside group (Malina \& Rohrbaugh 1992:88-89). Christian love surpasses this boundary. The renunciation of status has to do with abolishing a status hierarchy of "high" or "low" positions for people (see Theissen 1999:64, 287).

This value system presupposes an alter state of consciousness, a symbolic state which gives meaning to social life here and now. Baptism is an initiation into this alternative state. In the first century a transition of this kind was imagined in an apocalyptic ${ }^{11}$ thoughtworld. In Biblical times apocalyptic thinking (which was expressed in figurative language) was not seen as supernatural (in contrast to the natural world). The distinction between "natural" and "supernatural" is a Western culturally determined concept and is not useful for understanding first-century Mediterranean metaphysical concepts. This distinction was made for the first time in the ninth century (see Saler 1977:46, 51; cf Pilch 1996:134-135; Van Aarde 2001b:1165). In the Mediterranean culture of the first century a "spiritual" experience such as a transformation of baptism with water to a baptism into death pertains to an "alter state of consciousness".

11 Apocalyptic thinking comes to the front when religious people feel that they cannot alter their unbearable circumstances by themselves. Then they reach out to God for help. They believe that God will soon bring an end to this wicked world and bring a righteous world into existence (cf Rist 1989:157; Van Aarde 1994:79-80). 
Alter states of consciousness can be defined as "... conditions in which sensations, perceptions, cognition and emotions are altered. They are characterized by changes in sensing, perceiving, thinking, and feeling. They modify the relation of the individual to self, body, sense of identity, and the environment of time, space, or other people" (Bourguignon 1979:236).

An alter state of consciousness takes shape according to the culture in which it appears. Within the first century Mediterranean social world it usually appeared where people believed that they were suffering on account of the powers of external demonic forces, which brought about disasters such as illness, death or conflict. While they were powerless amidst their crisis, they "escaped" their world by taking refuge in a symbolical world where God was in control. Such a "spiritual" existence makes sense in a context of an alternative state of life in the presence of God. This can be explained as an "alter state of consciousness". Insight into the dynamics of alter states of consciousness can contribute to understanding the phenomenon modern Biblical scholars refer to as "apocalyptic".

Because of their apocalyptic worldview, Jesus followers let themselves be baptized and with this depicted their transition to an alternative lifestyle. The reason for baptism was to partake in the death and resurrection of Jesus Christ. The meaning of their baptism was the appropriation of new values and a changed lifestyle. This new lifestyle not only impacted their own lives. Their renunciation of status and the love for their neighbors also gave meaning to the lives of others.

\section{Works Consulted}

Beattie, J 1964. Other cultures: Aims, methods and achievements in social anthropology. London: Cohen \& West.

Berger, P L 1969. The sacred canopy: Elements of a sociological theory of religion. New York: Doubleday.

Boers, H 1989. Who was Jesus? The historical Jesus and the Synoptic Gospels. San Francisco, CA: Harper \& Row.

Bolle, K W 1987. s v "Myth: An overview". EncRel(E), Vol 10. 
Bourguignon, E 1979. Psychological anthropology: An introduction to human nature and cultural differences. New York: Holt, Rinehart \& Winston.

Bultmann, R 1972. The history of the Synoptic tradition, tr by J Mash. Rev ed. Oxford: Basil Blackwell.

Campbell, A 1999. Dying with Christ: The origin of a metaphor? in Porter, S E \& Cross, A R (eds), Baptism, the New Testament and the church: Historical and contemporary studies in honour of R E O White, 273-293. Sheffield: Sheffield Academic Press. (JSNT Suppl 171.)

Cassirer, E 1944. An essay on man: An introduction to a philosophy of human culture. New Haven, MA: Yale University Press.

Cassirer, E 1955. Philosophy of symbolic forms, II: Mythical thought. New Haven, MA: Yale University Press.

Collins, A J 1996. Cosmology and eschatology in Jewish and Christian apocalypticism. Leiden: Brill. (JSJ Suppl 50.)

Crossan, J D 1996. Who is Jesus? Answers to your questions about the historical Jesus. San Francisco, CA: Harper Paperbacks.

Crossan, J D 1998. The birth of Christianity: Discovering what happened in the years immediately after the execution of Jesus. San Francisco, CA: HarperSanFrancisco.

Duling, D C \& Perrin, N 1994. The New Testament: Proclamation and parenesis, myth and history. $3^{\text {rd }}$ ed. Fort Worth, TX: Harcourt Brace.

Eliade, M 1955. The myth of the eternal return. New York: Kegan Paul.

Elliot, N 2000. Paul and the politics of empire: Problems and prospects, in Horsley, R A (ed), Paul and politics: Ekklesia, Israel, Imperium, interpretation. Essays in honor of Krister Stendahl, 17-39. Harrisburg, PA: Trinity Press International.

Geertz, C 1973. The interpretation of cultures: Selected essays. New York: Basic Books.

Gehlen, R 1998. s v "Liminalität". HrwG, Band IV.

Girard, R 1972. La violence et le sacré. [Paris]: Grasset.

Hooker, M D 1997. The signs of a prophet: The prophetic actions of Jesus. London: SCM.

Hyatt, J P 1989. s v "Circumcision". IDB, Vol 1.

Jeremias, J 1960. Infant baptism in the first four centuries, tr by D Cairns. London: SCM. (The library of history and doctrine.)

Jeremias, J 1978. New Testament theology, Vol 1: The proclamation of Jesus, tr by J Bowden. London: SCM. 
Knobel, P S 1987. s v "Rites of passage: Jewish rites". EncRel(E), Vol 12.

Lang, B 1998. s v "Ritual/ritus". HrwG, Band IV.

Lindbeck, G A 1984. The nature of doctrine: Religion and theology in a postliberal age. Philadelphia, PA: Westminster Press.

Malina, B J \& Rohrbaugh, R L 1992. Social-science commentary on the Synoptic Gospels. Minneapolis, MN: Fortress.

Malinowski, B [1926] 1971. Myth in primitive psychology. Reprint. Westport, CT: Negro University Press.

Mc Fague, S 1983. Metaphorical theology: Models of God in religious language. London: SCM.

McVann, M 1988. The passion in Mark: Transformation ritual. BTB 189(3), 96-101.

McVann, M 1991a. Baptism, miracles, and boundary jumping in Mark. BTB 21(4), 151157.

McVann, M 1991b. Rituals of status transformation in Luke-Acts: The case of Jesus the prophet, in Neyrey, $\mathrm{J} \mathrm{H}(\mathrm{ed})$, The social world of Luke-Acts: Models for interpretation, 333-360. Peabody, MA: Hendrickson.

Meeks, W A 1993. The origins of Christian morality: The first two centuries. New Haven, MA: Yale University Press.

Meyer, M W (ed) 1987. The ancient mysteries: A sourcebook. Sacred texts of the mystery religions of the ancient Mediterranean world. San Francisco, CA: Harper \& Row.

Myerhoff, B G, Camino, L A \& Turner, E 1987. sv "Rites of passage: An overview". EncRel(e), Vol 12.

Myers, C 1990. Binding the strong man: A political reading of Mark's story of Jesus. Maryknoll, NY: Orbis Books.

Oepke, A 1968. sv bapto, baptizo, baptismos, baptisma, baptistes. TDNT, Vol 1.

Otzen, B [1976] 1980. The concept of myth, in Otzen, B, Gottlieb, H, Jeppesen, K, Myths in the Old Testament, 1-21. London: SCM Press.

Pearson, B W R 1999. Baptism and initiation in the cult of Isis and Sarapis, in Porter, S E \& Cross, A R (eds), Baptism, the New Testament and the church: Historical and contemporary studies in honour of R E O White, 42-62. Sheffield: Sheffield Academic Press. (JSNT Suppl 171.)

Pelser, G M M 1981. Die doop in die Nuwe Testament, met besondere verwysing na die doop deur onderdompeling en die kinderdoop. Bylae L, Agenda van Algemene Kerkvergadering, Nederduitsch Hervormde Kerk van Afrika. (Boek 105, Kommissie van die Algemene Kerkvergadering, Apr- Jun 1981.) 
Pilch, J J 1993. Visions in Revelation and alternate consciousness: A per-spective from cultural anthropology. Listening: Journal of Religion and Culture 28(3), 231-244.

Pilch, J J 1996. Altered states of consciousness: A "kitbashed" model. BTB 26(3), 133138.

Pilch, J J 2002a. Paul's ecstatic trance experience near Damascus in Acts of the Apostles. HTS 58(2), 690-707.

Pilch, J J 2002b. The nose and altered states of consciousness: Tascodrugites and Ezekiel. HTS 58(2), 708-720.

Reicke, B 1987. The historical setting of John's baptism, in Sanders, E P (ed), Jesus, the gospels and the church: Essays in honor of William R Farmer, 209-224. Macon: Mercer University Press.

Rist, M 1989. sv "apocalypticism". IDB, Vol 1.

Ritschl, D 1986. Konzepte: Ökumene, Medizin, Ethik. München: Chr. Kaiser Verlag. Saler, B 1977. Supernatural as a Western category. Ethos 5, 31-53.

Schrage, W 1988. The ethics of the New Testament, tr by D E Green. Philadelphia, PA: Fortress.

Schweitzer, A 1930. Die Mystik des Apostels Paulus. Tübingen: Mohr (Paul Siebeck). Soskice, J M 1985. Metaphor and religious language. Oxford: Claredon.

Stolz, F 1988a. Der mythische Umgang mit der Rationalität und der rationale Umgang mit dem Mythos, in Schmidt, H H (Hrsg), Mythos und Rationalität, 81-106. Gütersloh: Mohn.

Stolz, F 1988b. Grundzüge der Religionswissenschaft. Göttingen: Vandenhoeck \& Ruprecht. (KVR 1527.)

Tatum, W B 1994. John the Baptist and Jesus: A report of the Jesus Seminar. Sonoma, CA: Polebridge Press.

Theissen, G 1999. A theory of primitive Christian religion. London: SCM.

Theissen, G \& Merz, A 1996. Der historische Jesus: Ein Lehrbuch. Göttingen: Vandenhoeck \& Ruprecht.

Turner, V 1967. The forest of symbols: Aspects of Ndembu ritual. Ithaca, NY: Cornell University Press.

Turner, V 1969. The ritual process: Structure and anti-structure. Ithaca, NY: Cornell University Press. (Symbol, Myth, and Ritual Series.)

Turner, V 1974. Dramas, fields, and metaphors: Symbolic action in human society. Ithaca, NY: Cornell University Press.

Turner, V 1987. s v "Rites of passage: A few definitions". EncRel(E), Vol 12. 
Van Aarde, A G 1994. Kultuurhistoriese agtergrond van die Nuwe Testament: Die eerste-eeuse Mediterreense sosiale konteks. Pretoria: Kital.

Van Aarde, A G 2001a. Fatherless in Galilee: Jesus as child of God. Harrisburg, PA: Trinity Press International.

Van Aarde, A G 2001b. Millennialisme, eskatologie en apokaliptiek. HTS 57(3\&4), 1158-1178.

Van Aarde, A G \& Pelser, G M M 2001. “'n Oop en vry teologiese debat met werklike diepgang." HTS 57(1\&2), 7-48.

Van Gennep, A 1960. The rites of passage, tr by M B Vizedom \& G L Caffee. Chicago, IL: University of Chicago Press.

Van Staden, P 2001. Doop as ritueel van status-transformasie. HTS 57(1\&2), 576-592.

Waetjen, H C 1989. A reordering of power: A socio-political reading of Mark's Gospel. Minneapolis, MN: Fortress.

Wedderburn, A J M 1987. Baptism and resurrection: Studies in Pauline theology against its Graeco-Roman background. Tübingen: Mohr (Paul Siebeck). 